\title{
Principal Primary Sources and Abbreviations
}

$\begin{array}{lll}\text { Austen, Ralph } & \text { Fruit Trees } & \begin{array}{l}\text { A Treatise of Fruit-Trees (Ox- } \\ \text { ford, 1653). }\end{array} \\ \text { Spirituall Use } & \begin{array}{l}\text { The Spirinall Use of an Or- } \\ \text { chard; or Garden of Fruit- } \\ \text { Trees, in Fruit-Trees, cited } \\ \text { above. }\end{array} \\ \text { Blith, Walter } & \text { English Improver } & \begin{array}{l}\text { The English Improver, or a } \\ \text { New Survey of Husbandry } \\ \text { (London, 1649). }\end{array} \\ & \begin{array}{l}\text { English Improver } \\ \text { Improved }\end{array} & \begin{array}{l}\text { The English Improver Improved } \\ \text { or the Survey of Husbandry } \\ \text { Surveyed (London, 1653). }\end{array} \\ \text { Usefulnesse } & \begin{array}{l}\text { Some Considerations Touching } \\ \text { the Usefulnesse of Experimental }\end{array} \\ & \begin{array}{l}\text { Naturall Philosophy. Propos'd } \\ \text { in a Familiar Discourse to a }\end{array} \\ & \begin{array}{l}\text { Friend, by Way of Invitation to } \\ \text { the Study of It (2nd ed.; Ox- } \\ \text { ford, 1664-1671), vol. 1. }\end{array} \\ & \begin{array}{l}\text { A Large Letter Concerning the } \\ \text { Defects and Remedies of En- } \\ \text { glish Husbandry, Written to } \\ \text { Mr. Samuel Hartib, in Hart- } \\ \text { lib, Legacie, cited below. }\end{array} \\ & \end{array}$


xii

Dymock, Cressy

Evelyn, John

Hartlib, Samuel

Houghton, John

Locke, John
New Divisions

Kalendarium

Pomona

Sylva

Terra

Discoverie

Legacie

Letters

Conduct
A Discovery for New Divisions, or, Setting out of Lands, as to the Best Forme: Imparted in a Letter to Samuel Hartib, Esquire, in Hartlib, Discoverie, cited below.

Kalendarium hortanse (3rd ed.; London, 1669), in Evelyn, Sylva, cited below.

Pomona (London, 1670), in Evelyn, Sylva, cited below.

Sylva or a Discourse of ForestTrees and the Propagation of Timber in His Majesties Dominions (2nd ed.; London, 1670).

The Terra: A philosophical discourse of Earth, in Silva . . . (3rd ed.; York, 1801), vol. 2.

$A$ Discoverie for Division or Setting out of Land, as to the Best Form (London, 1653).

Samuel Hartib His Legacie: Or an Enlargement of $A$ Discourse of Husbandry Used in Brabant and Flaunders (London, 1652).

A Collection of Letters for the Improvement of Husbandry and Trade (London, 1681-83), 2 vols.

Of the Conduct of the Understanding, ed. Francis W. Garforth (New York: Teachers College Press, 1966). 
Correspondence

Education

Essay

Essay Concerning

Toletation

First Tract

First Treatise

Law of Nature

Poor Laws
The Correspondence of John Lacke, ed. E. S. de Beer (Oxford: Clarendon Press, 1976-), 8 vols.; 7 vols. to date.

Some Thoughts Concerning Education, in The Educational Writings of John Locke, ed. James L. Axtell (Cambridge: Cambridge University Press, 1968).

An Essay Concerning Human Understanding, 4th ed. (1700), ed. Peter H. Nidditch (Oxford: Clarendon Press, 1975).

"An Essay Concerning Toleration," in H. R. Fox Bourne, The Life of John Locke (London: King, 1876), vol. 1, pp. 174-94.

The First Tract on Government, in Two Tracts on Government, ed. and trans. Philip Abrams (Cambridge: Cambridge University Press, 1967).

Two Treatises of Government: A Critical Edition with an Introduction and Apparatus Criticus, ed. Peter Laslett (2nd ed.; Cambridge: Cambridge University Press, 1970).

Essays on the Law of Nature, ed. and trans. W. von Leyden (2nd impression; Oxford: Clarendon Press, 1958). "Proposal for Reform of the 


\begin{tabular}{|c|c|c|}
\hline & & $\begin{array}{l}\text { Poor Laws," in H. R. Fox } \\
\text { Bourne, The Life of John } \\
\text { Locke (London: King, 1876), } \\
\text { vol. 2, pp. 377-91. }\end{array}$ \\
\hline & Reasonableness & $\begin{array}{l}\text { The Reasonableness of Chris- } \\
\text { tianity, as Delivered in the } \\
\text { Scriptures, in Works, cited be- } \\
\text { low, vol. } 6 .\end{array}$ \\
\hline & Second Treatise & $\begin{array}{l}\text { Laslett edition cited above for } \\
\text { First } T \text { reatise. }\end{array}$ \\
\hline & 1668 & $\begin{array}{l}\text { Some of the Consequences That } \\
\text { Are Like to Follow upon Less- } \\
\text { ening of Interest to } 4 \text { Percent, } \\
\text { in William Letwin, The Ori- } \\
\text { gins of Scientific Economics: } \\
\text { English Economic Thought, } \\
\text { l660-1776 (London: Me- } \\
\text { thuen, 1963), pp. 273-300. }\end{array}$ \\
\hline & 1692 & $\begin{array}{l}\text { Some Considerations of the } \\
\text { Consequences of the Lowering } \\
\text { of Interest, and Raising the } \\
\text { Value of Money. In a Letter } \\
\text { Sent to a Member of Parlia- } \\
\text { ment, } 1691 \text {, in Works, cited } \\
\text { below, vol. } 4 .\end{array}$ \\
\hline & Toleration & $\begin{array}{l}\text { A Letter on Toleration, in Epi- } \\
\text { stola de Tolerantia: A Letter on } \\
\text { Toleration, ed. with preface by } \\
\text { Raymond Klibansky, trans. } \\
\text { with introduction and notes } \\
\text { by J. W. Gough (Oxford: } \\
\text { Clarendon Press, 1968). }\end{array}$ \\
\hline & Works & $\begin{array}{l}\text { The Works of John Locke (9th } \\
\text { ed.; London, 1794), } 9 \text { vols. }\end{array}$ \\
\hline Mascall, Leonard & New Art & $\begin{array}{l}\text { The Country-Mans New Art of } \\
\text { Planting and Graffing (Lon- } \\
\text { don, 1651). }\end{array}$ \\
\hline
\end{tabular}


Petty, Sir William

Reeve, Gabriel

Smith, Sir Thomas

Weston, Sir Richard
Political Arithmetick

Treatise

Directions

Republica

Discours
Political Arithmetick (London, 1690).

A Treatise of Taxes and Contributions (2nd ed.; London, 1667).

Directions Left by a Gentleman to His Sonnes for the Improoement of Barren and Heathy Land (London, 1670).

De republica anglorum, ed. Mary Dewar (Cambridge: Cambridge University Press, 1982 ), originally written in the early 1560 s and first published in 1583.

A Discours of Husbandrie Used in Brabant and Flaunders, Shewing Wonderful Improvement of Land There (1645), in Reeve, Directions, cited above. 
